\title{
Social Action Theory for a Public Health Psychology
}

\author{
Craig K. Ewart Department of Health Policy and Management, Johns \\ Hopkins University
}

Many illnesses can be prevented or limited by altering personal behavior, and public health planners have turned to psychology for guidance in fostering self-protective activity. A social theory of personal action provides an integrative framework for applying psychology to public health, disclosing gaps in our current understanding of self-regulation, and generating guidelines for improving health promotion at the population level. A social action view emphasizes social interdependence and interaction in personal control of health-endangering behavior and proposes mechanisms by which environmental structures influence cognitive action schemas, self-goals, and problem-solving activities critical to sustained behavioral change. Social action theory clarifies relationships between social and personal empowerment and helps explain stages of self-change.

Every year millions of people suffer and die of illnesses that could be curbed or eliminated by altering patterns of personal behavior. Modifiable habits and customs contribute to malnutrition, communicable diseases, and chronic illnesses, and thereby augment a staggering toll of needless deaths (Elder, 1987). To lower this toll, public health planners have turned to psychology-and especially to its models of self-regulation-for guidance in fostering self-protective action among those at risk. Yet psychological theories and models often seem of limited value when applied to public health problems, and some public health theorists have questioned their usefulness in the global struggle against disease (Jeffery, 1989; Leventhal, Cleary, Safer, \& Gutman, 1980). I argue that psychology does have a role to play, but that this role is constrained by inattention to pathways by which social environmental phenomena affect cognitive and biologic regulatory processes. I propose a theory of personal action designed to foster social-contextual analysis of personal change. This analysis poses important questions for selfregulation theory and discloses new opportunities for psychology to contribute to human health and well-being.

\section{Public Health and Psychology}

The term public health embraces a diverse array of problem-solving and health-protective activities inspired by the practice of viewing illnesses in a social context. By relating the afflictions of individuals to the groups to which they belong or to the environments in which they work and live, the public health outlook differs from that of clinical medicine, which treats diseases as attributes of isolated sufferers. This social-contextual approach has advanced disease control and enhanced quality of life in ways that would not have been possible in a clinical model. Early attempts to determine who became sick, and where and when, for example, led to significant reductions in the prevalence of infectious diseases long before the biological mechanisms of these illnesses could be explained or modified. A population perspective can reveal a previously unrecognized environmental hazard or a widespread health-endangering personal behavior that when altered even slightly may reduce the burden of human suffering and lower the cost of medical care. This perspective has led to public health's long-standing emphasis on disease prevention and on viewing the entire community - rather than the individual-as the patient.

Public health's interest in individuals and in processes of personal change has increased, however, with mounting evidence linking major health threats to modifiable human behaviors (Sexton, 1979; Surgeon General, 1979). Public health is an empirically driven, problemfocused enterprise that looks to various disciplines for needed theoretical and technical resources. Yet those who would apply behavior change methods of psychology to populations quickly discover that these efforts can go awry (Jeffery, 1989). Interventions directed at individuals can prove more expensive than the "passive" environmental prevention strategies long championed in the public health movement and may unintentionally "blame the victim" by implying that people are personally responsible for illnesses caused by unhealthy physical and social environments (Runyan, DeVellis, DeVellis, \& Hochbaum, 1982; Williams, 1982). Moreover, the dominant diagnostic model in public health envisions an interaction between a host (e.g., disease victim), an agent (e.g., healthdamaging organism or substance), and the environment. Psychological theories focus on the host. They explain important phenomena of individual learning, memory, choice, and performance. Yet public health planners often have difficulty applying these theories to the practical tasks of designing protective legislation, educating the public, and fashioning healthier occupational work or living environments (Faden, 1987). These tasks require a multileveled conception that views host processes as subcomponents of larger social and environmental systems.

Preparation of this manuscript was supported in part by Grant R01HL36298 from the National Heart, Lung, and Blood Institute.

I thank Lawrence Kincaid and Donald Steinwachs for their helpful comments on an earlier draft.

Correspondence concerning this article should be addressed to Craig K. Ewart, Health Services R \& D Center, Johns Hopkins School of Hygiene and Public Health, 624 North Broadway, Baltimore, MD 21205. 


\section{Self-Regulation}

By the mid 1970s, interventions based on social learning principles were seen to offer the most effective, widely applicable method for changing behaviors that contributed to leading causes of preventable deaths (e.g., Bandura, 1969; Kanfer, 1977). With its emphasis on cognitive mediation of learning through modeling and vicarious reinforcement, social learning theory stimulated the creation of interventions to prevent heart disease and cancer by altering habits related to eating (Stunkard \& Penick, 1979), smoking (Leventhal \& Cleary, 1980), exercise (Martin et al., 1984), and substance use (Marlatt \& Gordon, 1985). These developments provided both a theoretical and a practical foundation for communitywide interventions such as the Stanford Five-Community Study (Farquhar et al., 1985) and the Minnesota Heart Health Program (Blackburn et al., 1984). During the 1980s, social learning theorists expanded their purview to include a variety of cognitive phenomena subsumed under the rubric "social-cognitive theory" (Bandura, 1986), and control and systems concepts were incorporated into models of self-regulation (Bandura, 1989; Carver \& Scheier, 1981; Hyland, 1988; Schwartz, 1983). Goals, feedback functions, and attendant systems constructs helped delineate processes by which people overcame destructive behavior patterns and strengthened self-protective capabilities (Weinstein, 1988).

\section{Social Action Theory}

Although these developments expand a theory of personal change, they do not meet public health's need for a contextual theory of individual action that incorporates modifiable social and personal mechanisms of self-control within an environmental model. Those who would encourage self-regulation on a wide scale require a framework for solving the problems that have hindered attempts to implement self-change as a public health strategy (Leventhal, Zimmerman, \& Gutman, 1984), including the challenge of defining appropriate self-regulatory goals, the problem of identifying causal mechanisms that can be activated to facilitate these goals, and the task of uncovering social-contextual influences that constrain or enhance self-regulatory mechanisms and thus provide targets for political, economic, or organizational change.

This article responds to this need by proposing a conceptual model with three dimensions representing selfregulation as a desired action state, an ensemble of interrelated change mechanisms, and a subcomponent of larger social environmental systems that contextually determine how personal change mechanisms operate. The proposed framework seeks to identify self-regulatory phenomena of public health importance, stimulate a desire to understand them, and set forth basic assumptions to guide the development of new theories, models, and exemplars (Kuhn, 1977; Rappaport, 1987). In this view, interventions to encourage self-regulation belong to the public health tradition of innoculation. As immunization strengthens the self-regulatory capabilities of the immune system, so behavioral interventions strengthen self-regulatory systems that foster capacity for self-protective action (Ewart, in press). These self-regulatory systems can be viewed as interconnected cybernetic control loops operating at physiologic, cognitive, and social levels (Seeman, 1989).

Applying the framework to an analysis of population interventions discloses gaps in our current understanding of self-regulation and suggests how public health strategies targeting individuals might be improved. To highlight these problems and possibilities, I apply here the tripartite model to self-regulation of coronary and cancer risk behaviors involving diet, physical activity, and tobacco or alcohol use, as these have generated the largest health literature on self-regulation. The model's three dimensions (Figure 1), respectively, emphasize the role of social context in maintaining health routines or habits (action state dimension), provide a causal framework linking selfchange processes to interpersonal environments (process dimension), and specify macrosocial and environmental influences that empower or constrain personal change (contextual dimension). ${ }^{2}$

\section{Self-Regulation as an Action State}

The first challenge in public health intervention is to define appropriate self-regulatory goals. In most cases, prevention entails creating self-protective habits in the form of highly routinized and "automatic" action sequences that lower personal risk. Health habits are easily represented by a simple action-outcome feedback loop, in which self-regulation is a condition of self-sustaining, dynamic equillibrium between self-protective activities and their experienced biologic, emotional, and social consequences. Habitual eating, exercise, smoking, or drinking activities tend to follow predictable scripts, in which successive events in an action sequence reinforce preceding acts and guide subsequent action components (Kazdin, 1984; Schank \& Abelson, 1977). These scripts tend to be highly integrated, in that one can perform them without consciously attending to component actions that compose the larger sequence (Abelson, 1981). Moreover, they often co-occur with other habitual acts, as when eating, smoking, or drinking are embedded in social or recreational events. This makes unwanted habits hard to change; conversely, the assimilation of desired habits into other rou-

I "Behavioral innoculation" can be effected via legal or environmental changes that encourage people to take self-protective action against a health threat. Laws requiring seat-belt use and buzzers reminding passengers to attach their belts represent innoculation approaches to preventing automobile injuries, whereas laws mandating air bags in vehicles-by reducing the need for personal action-represent public health's "sanitary" tradition of removing health threats from human environments. Research on self-regulation thus may aid legal and environmental intervention, as well as public education.

${ }^{2}$ The model also applies to behaviors contributing to malnutrition and to communicable diseases that, although less studied by psychologists, account for a far greater portion of the world's preventable deaths. For applications to third-world health problems and settings, see Elder (1987), and Elder, Schmid, Hovell, Molgaard, and Graeff, (1989). 
Figure 1

Social-Contextual Model of Self-Regulation

1. SELF-REGULATORY GOALS:

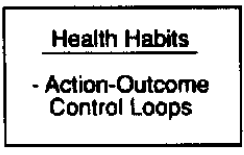

2. BELF-REGULATORY PROCESSES:
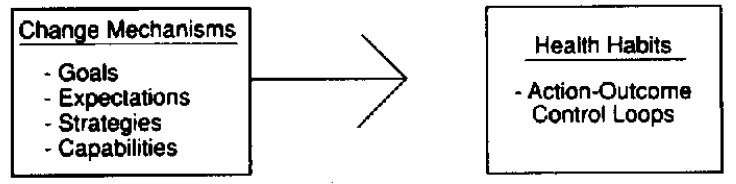

3. SOCIAL ACTION MODEL:

\begin{tabular}{|c|c|c|}
\hline Action Contexts & Change Mechanisms & Health Habits \\
\hline $\begin{array}{l}\text { - Physical } \\
\text { - Social } \\
\text { - Biological } \\
\text { - Mood/Arousal }\end{array}$ & $\begin{array}{l}\text { - Goals } \\
\text { - Expectations } \\
\text { - Strategies } \\
\text { - Capabilities }\end{array}$ & $\begin{array}{l}\text { - Action-Outcome } \\
\text { Control Loops }\end{array}$ \\
\hline
\end{tabular}

Note. 1. The goal of self-regulation is to create action-outcome control loops that sustain health-protective routines; 2 . the process of self-regulation entails activating social-cognitive mechanisms to generate desired control loops; 3 social and biological contexts of self-regulation facilitate or constrain these mechanisms and thus determine long-term success in habit modification.

tines renders protective diet, exercise, or similar regimens easier to sustain (Ewart, in press).

In this feedback model, actions are guided by their consequences in a negative control loop; variations in monitored outcomes (immediate and delayed) evoke compensating behavioral adjustments. The result is a steady but continuously oscillating action state, in which the frequency of the diet, exercise, or other behavior fluctuates around some stable set point (D. H. Ford, 1987). The control loop implies that the starting place in developing public health interventions is with an analysis of the relationships between health-endangering action sequences and their experienced effects. This analysis can disclose the point at which problematic action scripts are most vulnerable to prevention, and suggest effective procedures for constructing new scripts to protect health (Ewart, in press). The action state model thus helps the intervention planner identify critical action components and specify desired replacement sequences and outcomes.

The functional feedback loop described here represents a dominant view in current models of self-regulation and, in a broader sense, exemplifies an evolutionary social behaviorism explicitly or tacitly assumed in the post-Darwinian functionalism of James, Freud, and Piaget, as well as in contemporary operant, social-cognitive, and psychoanalytic theories. The fact of its perpetual reemergence in diverse forms over the past century suggests that this feedback mechanism ranks as one of the more significant discoveries of modern experimental and clin- ical psychology (Woodward, 1982). Yet attempts to modify health habits in community-based prevention disclose that the intrapersonal control loops emphasized in psychological theories are connected to interpersonal control systems: Personal action scripts are socially intertwined with scripts of family members, friends, or others in ways that pose significant obstacles to long-term change (M. H. Becker \& Green, 1975; Sallis, Grossman, Pinski, Patterson, \& Nader, 1987). Public health applications reveal a need to expand individually focused action state conceptions by including interdependence with others as a determinant of sustained behavior change.

\section{Social Interdependence}

Figure 2 incorporates social interdependence into the action state model. A close social relationship is one in which important action scripts of the people involved are interlinked; each individual in the relationship has the ability to facilitate or impede the other's sequences and thus affect their ability to attain valued goals related to love, work, self-care, or other desired ends (Clark \& Reis, 1988). These interlinked scripts frequently serve multiple goals. Preparing and sharing a meal, for example, allows family members to satisfy hunger, give and receive emotional support, amuse themselves, and plan the next day's activities (Bersheid, 1983). Social closeness can be defined in terms of the number of interlinked scripts and by the number of goals these linked sequences serve. As closeness increases, so does the probability that one person's attempt to alter a simple routine will disrupt valued routines and goals of intimate others, causing frustration and anger (Manne \& Zautra, 1989; Ruehlman \& Wolchik, 1988). Changes that disrupt action sequences at a point close to

\section{Figure 2}

Action State Model Representing Self-Regulation as a Negative Control Loop Maintaining Habitual Action Sequences or Routines

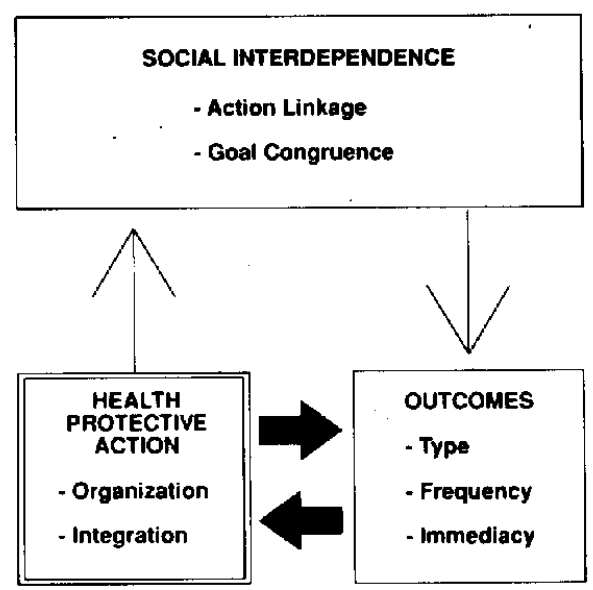

Note. The model incorporates social interdependence (script linkage) into the conventional action-outcome feedback model. 
the goal are more likely to provoke anger than are interruptions that occur farther from the goal (Mandler, 1975). A partner's negative reactions to interrupted routines can undermine commitment to new patterns of health behavior.

Note that in this model the degree of disruption, and hence of support from a helper, is predicted by the degree to which the helper's valued action scripts are interdependent with the action scripts of the person needing support (i.e., the degree of action linkage). This explains why measures of relationship satisfaction often fail to predict family members' responses to a member's change of diet, exercise, or other routines; behavioral support is a function of action linkage, whereas relationship satisfaction reflects the degree to which one's goals for the relationship are being met (Ewart, in press). Families characterized by high levels of cohesion and satisfaction (Olson, Sprenkle, \& Russell, 1979) may prove surprisingly unsupportive when important interlinked routines are repeatedly disrupted (Coyne, Wortman, \& Lehman, 1988); and family environments characterized by lower levels of cohesion or satisfaction may be conducive to behavior change if action linkage also is low.

Self-regulation theorists have devoted scant attention to the counterintuitive notion that relationship closeness may be a risk factor for nonadherence, and few have considered that daily routines are as likely to disrupt health- promoting action scripts as are health beliefs or attributions (Lichtman et al., 1984). Research examining the effect of script interdependence on health habit change has the potential to tie self-regulation theory to social contexts and to suggest methods for identifying and uncoupling potentially problematic action linkages (Bersheid, Snyder, \& Omoto, 1989).

\section{Processes of Self-Change}

Behavioral interventions in populations require an action model that offers explicit procedural guidelines for encouraging personal self-regulation (Leventhal, Zimmerman, \& Gutman, 1984). The action state model effectively describes habitual activities in which people react to feedback discrepancies occasioned by disrupted routines but does not fully represent processes involved in creating new action scripts or modifying ones that prove ineffective. The latter processes include "feed-forward" mechanisms by which people create new goals, alter self-standards, fashion behavioral strategies, and select new environments (cf. D. H. Ford, 1987, pp. 67-69). Socialcognitive research has identified a number of mechanisms that enable people to make transitions from old action states to new ones, and thus to change. It is useful to view these transition processes as interacting components within a general causal model, as in Figure 3. Figure 3

\section{Figure 3}

Process (Self-Change) Model Representing Self-Regulation as a Coordinated Ensemble of Interacting Cognitive Processes and Capabilities

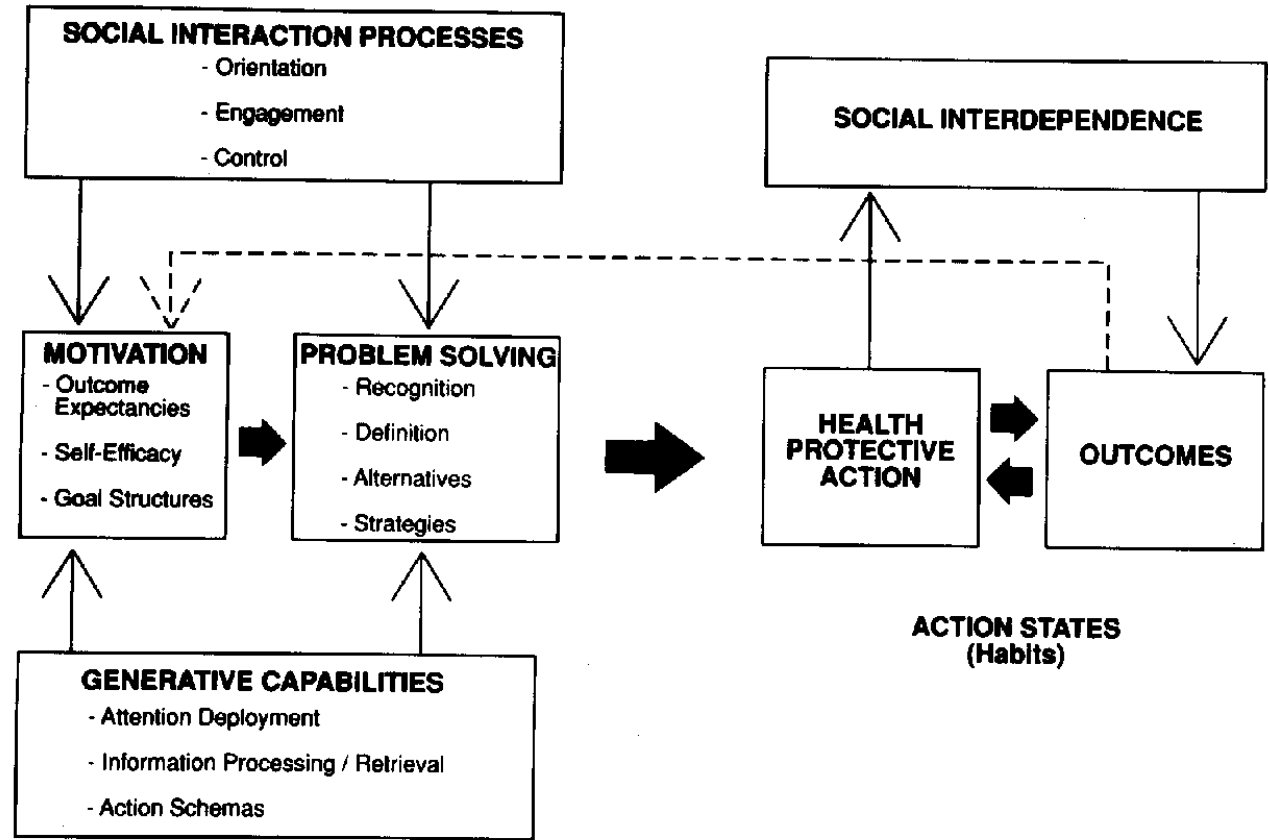

SELF-CHANGE PROCESSES

Note. The model incorporates action capabilities of microsocial relationship systems (social interaction processes) into a general causal model of personal change. 
introduces a process dimension to indicate that action states arise from strategies people use when trying to regulate their behavior, and that the creation of strategies is prompted by motivational appraisal processes. The ability to make appraisals and translate them into strategies is a function of health-relevant procedural and factual knowledge (generative capabilities), as well as the interpersonal skills possessed by oneself and by others with whom one's action scripts are interlinked (social interaction component). Note that self-change processes (Figure 3) are connected with action states via the broken line shown in the figure: Disturbance of an action state due to internal changes (e.g., fatigue or illness) or external causes (e.g., disrupted interdependence) may stimulate reappraisal, renewed problem solving, and strategy implementation, even as changes in appraisals, by suggesting new goals and strategies, may alter existing action states.

In addition to providing targets for intervention, process mechanisms suggest testable pathways through which environments can affect health behavior and provide new ways for public health epidemiologists and planners to envisage and to investigate person-environment interactions. I will return to this important point later when discussing contextual influences.

\section{Problem Solving}

Models of health behavior usually ascribe changes in health habits to changes in health knowledge, beliefs, attitudes, or contingencies of reinforcement (Janz \& Becker, 1984; Leventhal et al., 1984). It is becoming evident, however, that problem-solving activities mediate the impact of these motivators; persuasive inducements affect behavior only to the degree that they prompt people to create appropriate self-change strategies. Strategies function as action guides for specific situations and range from simple if-then rules used without active awareness (Linville \& Clark, 1989) to carefully constructed constellations of thoughts, feelings, and actions that help an actor regulate arousal, exert control over outcomes, make choices, and persist in the face of difficult obstacles (Dweck \& Leggett, 1988; Kihlstrom, 1987; Langer, 1989).

Research conducted in the past decade suggests that the ability to generate effective strategies for handling dayto-day problems is related to social and emotional adjustment, and that adjustment can be enhanced by problem-solving training (D'Zurilla, 1986; Nezu, 1986; Nezu \& Perri, 1989). Moreover, it appears that problem-solving activities constitute the fulcrum of the habit-change process. Adherence to dietary regimens is correlated with problem-solving skill in adults (Fehrenbach \& Peterson, 1989; Glasgow, Toobert, Riddle, Donnelly, \& Calder, 1989 ) and in adolescents (Hanna, Ewart, \& Kwiterovich, 1990). Including problem-solving training in behavioral weight-loss interventions has been shown to effect greater weight loss than has comparable behavioral intervention without problem-solving training (Black \& Scherba, 1983; Graves, Myers, \& Clark, 1988). These findings suggest that, rather than focus only on target behaviors, public health interventions should encourage and enable people to identify potential obstacles to self-change and generate appropriate strategies to overcome them.

\section{Motivational Processes}

People are neither impelled by attitudes nor mindlessly pulled by reinforcers. Instead, they actively motivate themselves by envisaging possible outcomes, evaluating their capabilities, and generating goals that guide and energize problem solving.

Outcome expectancies. Decisions to adopt healthprotective behaviors are influenced by expectations that a recommended action will protect or enhance valued resources or outcomes (Bandura, 1986; Janz \& Becker, 1984; Rogers, 1983). Anticipated outcomes include the health-promoting activity's intrinsic effects (e.g., the pleasant physical sensations it produces), as well as its more extrinsic material and social consequences (e.g., enhanced personal appearance, social approval, reduced risk). People contemplating a difficult action such as quitting smoking carefully weigh the pros and cons of acting; the relative importance they attribute to desired and undesired consequences of trying to quit predicts the probability of their acting, as well as the likelihood of their maintaining prolonged abstinence (Velicer, DiClemente, Prochaska, \& Brandenburg, 1985). Leventhal and his associates (Baumann \& Leventhal, 1985; Leventhal, Meyer, \& Nerenz, 1980) have underscored the role of cognitive appraisals by demonstrating that many health choices are shaped by erroneous expectancies derived from idiosyncratic and incorrect "theories of illness." Public health interventions can alter outcome expectancies by drawing attention to naturally occurring outcomes (e.g., emphasize immediately experienced benefits of exercise or diet change), as well as by introducing contrived incentives (e.g., lottery prizes). In the case of behaviors that are comparatively uncomplicated or easy to perform (e.g., switching to a higher fiber cereal), significant widespread change often can be effected by providing information about action-consequence relationships and by introducing simple prompts into situations in which the self-protective action should be performed (e.g., the grocery store shelf; Geller, Winett, \& Everett, 1982).

Although research in health belief and reasoned action frameworks indicates that outcome expectations influence health behavior, these formulations leave large proportions of behavioral variance unexplained (M. H. Becker, 1990), thus suggesting the need to identify the contributions of other motivational processes.

Self-efficacy. A desire to change does not stimulate problem solving unless one believes oneself to be capable of performing the recommended action (Bandura, 1977, 1986). Unfortunately, people often are unduly pessimistic about their capabilities. Prime examples include the many Americans with elevated cardiovascular risk factors who fail to change their diet and exercise patterns despite a desire to do so (Oldridge, 1982). Research in this large and important population dramatically illustrates the power of self-appraisal: In high-risk individuals, increases in self-efficacy following a treadmill exercise test predict 
subsequent compliance with prescribed exercise routines better than do treadmill performance or electrocardiogram data derived from the test (Ewart, Stewart, Gillilan, Keleman, Valenti, et al., 1986; Ewart, Taylor, Reese, \& DeBusk, 1983). Moreover, self-perceived ability to exercise prior to participating in aerobic exercise training predicts posttraining gains even after controlling for pretreatment capability (Ewart, Stewart, Gillilan, \& Kelemen, 1986).

Research on the origins of self-efficacy suggests ways to enhance one's personal confidence by means of low cost, widely applicable interventions involving social modeling and graduated performance of feared activities (Bandura, in press; Ewart, 1989b, 1990). In people who fear exercise, self-efficacy can be strengthened by performing simple, safe exercise tests. By providing confidence-building interpretation of test results as part of standard medical evaluation, self-efficacy can be enhanced (Ewart, Taylor, et al., 1983). Principles of self-efficacy enhancement also can be applied to public health communications to promote participation in preventive screening (Rippletoe \& Rogers, 1987).

Goal structures. Although experimental analyses of self-regulation usually examine isolated behavioral responses, epidemiologic studies of eating, exercising, or smoking show that these and other health habits belong to larger clusters of action scripts directed toward some greater goal, and that such clusters are more prevalent in some population subgroups than in others (Donovan, Jessor, \& Costa, 1988). This discovery challenges selfregulation theorists to explain how action clusters are formed and how these structures might affect population responses to behavior change appeals. Contemporary social-cognitive approaches to personality provide constructs that may prove useful in addressing these questions. Recent work on personal "strivings" (Emmons, 1986), "projects" (Little, 1983), "tasks" (Cantor, Norem, Niedenthal, Langston, \& Brower, 1987), and "social goals" (M. E. Ford, 1982), for example, suggests that action clusters are constituted by an individual's personal projects. These projects respond to basic tasks of living such as achieving social influence, being accepted by others, acquiring material resources, establishing intimacy, or protecting personal safety. Projects change over time as different age-graded normative tasks become critical to negotiating successive developmental phases of the life span (Caspi, 1987). For example, eating large quantities of junk foods and experimenting with tobacco, alcohol, or drugs compose a cluster that may serve an adolescent's goal of being accepted by peers (Jessor, Chase, \& Donovan, 1980), whereas in an adult, behaviors composing this cluster often increase in an effort to manage job stress (Johansson, Johnson, \& Hall, 1991). Positive affect is associated with the perception that important goals are being attained and that negative affect is associated with low expectations of success or with conflicts among one's various goals (Emmons \& King, 1988, 1989; Ruehlman, 1985).

Projects affect the creation of self-protective action patterns by causing people to generate self-directive goals or behavioral intentions (Fishbein \& Ajzen, 1975; M. E. Ford \& Nichols, 1987), together with standards for evaluating one's performance (Bandura, 1988). Directive goals embodied in personal projects guide people into activities and environments that affect their responses to behavior change inducements. Health behavior changes seen to facilitate important projects will be adopted more easily than changes that appear less compatible (Eiser \& Gentle, 1988), even when the latter are viewed as desirable (outcome expectancy) and feasible (self-efficacy). For example, after a heart attack, patients are more likely to follow a rehabilitative exercise regimen if they strongly want to recover energy needed to resume a challenging career than if they are concerned with minimizing discomfort or avoiding work stress (Oldridge, 1982). Encouraging weight-loss clients to reflect on their commitments and priorities has been shown to help them integrate dietary change objectives with valued goals and thus facilitate clinic-based weight loss (S. H. Schwartz \& InbarSaban, 1988). By surveying people's projects, public health planners can gain important insights into higher order goals that motivate a target population, and thus discover ways to make an intervention more attractive to those it is meant to serve.

In addition to developing directive goals, people formulate self-standards by which to judge the adequacy of their efforts. Attaining a goal results in self-approval and thus stimulates further goal-directed effort (Bandura, 1989). Public health campaigns can stimulate change by activating self-evaluation, but goal theories differ as to whether easy, difficult, or moderately challenging standards inspire the greatest effort (Bandura, 1988; Locke, Shaw, Saari, \& Latham, 1981). It appears that the optimal level of challenge depends on the nature of the directive goal (Hyland, 1988). When the directive goal is a physical state, such as achieving a lower blood cholesterol level or lower body weight, comparatively easy goals (e.g., try $2 \%$ milk before switching to skim milk; lose only one pound per week) are most effective as they make attaining the desired end state easier and more certain. On the other hand, when the directive goal is to enhance a protective skill, such as mastering a health-promoting sport or selfcontrol technique, moderately difficult goals should generate greater persistence as they ensure a sense of achievement and provide more informative feedback about one's capabilities than do very easy or very difficult goals (Bandura \& Schunk, 1981).

Judgments concerning personal capabilities and selfgoals are interactive subprocesses; directive goals and selfstandards affect self-efficacy, and self-efficacy appraisals guide the selection of action strategies. This interactive view raises important questions for social-cognitive theory. For example, interventions to enhance self-efficacy may prove more effective when a person's valued projects aim at achieving mastery goals such as skill or strength enhancement than when projects serve end states such as increasing physical comfort or enjoyment (S. H. Schwartz \& Inbar-Saban, 1988). 


\section{Generative Capabilities}

The acts of solving a problem, formulating a goal, appraising one's capabilities, or foreseeing the consequences of behavior draw on various forms of knowledge or schemas. Cognitive schemas represent organized knowledge sets that direct one's attention to specific aspects of situations and environments, guide the encoding of experiences in long-term memory, and provide procedural routines for performing familiar tasks (Winfrey \& Goldfried, 1986). Declarative knowledge schemas represent facts and beliefs about oneself, one's body, and the social and physical world, whereas procedural schemas consist of skills and rules for applying declarative knowledge (Anderson, 1983). Together, these knowledge forms comprise generative capabilities that allow one to envisage alternative goals and create novel action strategies (Linville \& Clark, 1989). As enablers of motivation and problem solving, these generative capabilities constitute important mechanisms by which social and physical environments affect self-regulatory acts.

A class of procedural schemas critical to self-control was noted a century ago by William James (1890/1950), who observed that the essential act of will (self-regulation) involves "attending to a difficult object" in the form of an imagined possibility that inhibits or energizes action. Contemporary research supports this insight (Kanfer, 1980) and demonstrates that self-control is facilitated by skill in cognitively transforming distressing thoughts and aversive stimuli (McCaul \& Malott, 1984). Developmental studies of children's ability to delay gratification in the face of temptation reveal that delay is related to the acquisition of attention deployment strategies used during the waiting interval, knowledge of delay rules, and intelligence (e.g., Rodriguez, Mischel, \& Shoda, 1989).

Social action theory suggests that cognitive control schemas influence behavioral choices by increasing confidence in one's ability to persist in temptation avoidance. This is supported by examination of eating habits in a recent epidemiologic study (Slater, 1989). Individuals' confidence in their ability to control distressing thoughts and ruminations (cognitive control) predicted their selfefficacy for controlling eating behavior, and self-efficacy (but not cognitive control) predicted their dietary habits. Experimental studies provide further evidence that selfefficacy mediates the influences of cognitive schemas; attending to obstacles that might impair one's ability to perform an experimental task lowers self-efficacy, and lowered self-efficacy subsequently is associated with impaired performance (Cervone, 1989). Teaching attentional control techniques for pain management improves selfefficacy for pain control, which in turn is associated with increased pain tolerance (Bandura, O'Leary, Taylor, Gauthier, \& Gossard, 1987).

Desire to mobilize control skills is influenced by declarative (factual) knowledge. People resort to personal illness representations (Leventhal, Meyer, \& Gutman, 1980; Meyer, Leventhal, \& Gutman, 1985) to interpret felt symptoms and diagnostic labels; these representations can impair ability to appraise risk or anticipate possible consequences of health-endangering actions (Weinstein, 1988). Public health interventions can enhance action capabilities by altering inaccurate schemas and providing useful knowledge and skills. In addition to cognitive control skills, helpful procedural schemas include skills for evaluating health-relevant information (e.g., TV commercials, product labels) and reflecting on one's problemsolving efforts. For example, simply teaching people to monitor and evaluate their problem-solving progress improves the quality of solutions achieved (Kluwe \& Friedrichsen, 1985), and focusing one's attention on the process of problem solving is more helpful than focusing on the final goal (Kuhl, 1985). Mentally envisaging oneself performing a chosen strategy prior to enacting it increases the probability of success (Nuttin, 1984; Wilensky, 1983).

Novel schemas are most easily assimilated when presented in the form of a story about an actor (model) who successfully confronts a problem scenario in which the instigating conditions and the actor's goals, behavior sequences, and experienced outcomes are clearly specified (Bandura \& Jeffery, 1973; Winett, King, \& Altman, 1989). Retention is enhanced when this material is presented following principles known to facilitate cognitive encoding and retrieval of health-relevant information (Ley, 1977). It appears that schemas involving core assumptions about personal vulnerability may be more difficult to change than schemas representing procedural routines or facts about illness (Janoff-Bulman, 1989). People are more likely to revise vulnerability schemas in response to crises and during transitions into new environments (Cantor, 1990), suggesting that risk education might target those undergoing life changes or experiencing an illness or death in their immediate social network (D. Becker \& Levine, 1987).

\section{Social Interaction Processes}

Although self-regulation theorists have tended to view action capabilities as properties of the individual, a socialcontextual view asserts that these abilities are also a function of an individual's close personal relationships (Ewart, 1990; McFall, 1982). When behavior changes threaten to disrupt a valued relationship, a satisfactory outcome depends on the partners' ability to collaborate effectively in problem solving; that is, success depends on partners' conjoint (as opposed to individual) social capabilities. These capabilities can be enhanced by simple, cost-effective interventions that can be widely implemented in health care settings. For example, including a cardiac patient's spouse in an exercise stress-test protocol has been shown to increase couple agreement concerning the former's physical abilities, thereby removing a significant interpersonal obstacle to exercise compliance for tertiary prevention (Taylor, Bandura, Ewart, Miller, \& DeBusk, 1985). In a city clinic serving low-income Black outpatients, including a family member in brief, behaviorally specific counseling and regimen planning increased the patient's long-term compliance with antihypertensive medications, resulting in improved blood pressure con- 
trol, and reduced mortality over a five-year follow-up interval (Levine et al., 1979; Morisky et al., 1983). These interventions presumably operate by altering the relevant knowledge schemas of each of the parties (e.g., demonstrating to a spouse what the patient can do) and promoting shared projects, increasing self-efficacy, and building shared commitment to a specific plan of action (Black, Gleser, \& Kooyers, 1990).

To increase relationship support for self-regulation, it is necessary to clarify the origins of conjoint (relationship) competence and to determine how interpersonal processes and capabilities influence personal self-control. Research on marital communication and problem solving suggests that a relationship's competence is a function of dyadic orientation processes, defined in terms of the frequency, skill, and persistence with which both partners attempt to understand each other's goals, identify shared objectives, separate conflict over one goal or project from other relationship goals and projects, and endorse or validate each other's strivings (Gottman, Notarius, Gonso, \& Markman, 1976). These activities are facilitated by engagement processes including reflective listening, efforts to distinguish a communication's intent from its felt impact, and attempts to translate general criticisms into behaviorally specific requests (Jacobson \& HoltzworthMonroe, 1986). Relationship competence is also increased by control processes, such as specifying clear and attainable goals, developing action plans, and monitoring their implementation (Jacobson \& Margolin, 1979). Relationship deficits in orientation, engagement, and control competence are associated with elevated blood pressure during marital conflict in persons with essential hypertension (Ewart, Taylor, Kraemer, \& Agras, 1991), and conjoint training that targets these skills reduces cardiovascular reactivity during family arguments (Ewart, Burnett, \& Taylor, 1983; Ewart, Taylor et al., 1984).

Research on social support indicates that the availability of a trusted confidant (typically a spouse) appears to be the critical factor determining whether people feel they are adequately supported in coping with difficult challenges (Heller, Swindle, \& Dusenbury, 1986). The analysis of relationship competence identifies interpersonal processes conducive to sustained self-regulatory support. It suggests that people will anticipate greater support for self-protective activities and feel more confident in their ability to change if they and a trusted other are able to (a) report multiple mutual goals and projects, (b) describe their relationship conflicts in terms of specific situations and behaviors, and (c) engage in collective goalsetting and monitoring (control) activities. Manipulating these relationship capabilities in studies of behavioral adherence might disclose more effective ways to increase social support for self-protective action.

\section{Social Environmental Determinants of Self-Regulation}

Social-cognitive theories explain self-regulation in terms of internal processes and transactions with one's imme- diate milieu. A public health perspective, however, views individual self-regulation as a subcomponent of larger environmental systems. These systems create contextual influences (the third term in the host-agent-environment paradigm) that constrain or facilitate self-protective acts. A contextual model (Figure 4) thus completes the public health paradigm by indicating how environments affect self-change processes (Figure 3 ) to disrupt or maintain a given action state (Figure 2). The model guides social and organizational intervention to encourage personal change.

This model also challenges the dominant public health view of person-environment interaction, which is a simple mechanistic conception of biological susceptibility interacting with an environmental hazard (e.g., lung cancer risk increases synergistically in workers whose nicotine-damaged lungs are exposed to airborne asbestos fibers). Although simple mechanistic models can explain many public health risks, social action theory introduces the possibility of more dynamic, reciprocal relationships between persons and environmental contexts. Personal goals, expectations, skills, and strategies cause individuals to seek or create environments that satisfy their strivings and suit their capabilities (Emmons, Diener, \& Larsen, 1986); this reciprocal conception helps explain risks that arise and persist because people actively choose environments that support health-endangering goals and plans. For example, longitudinal data from the Framingham heart disease study suggest that people tend to select marriage partners whose degree of obesity, smoking, alcohol use, and dietary habits match their own (Sackett, Anderson, Milner, Feinleib, \& Kannel, 1975). In this view of interaction, contexts modify personal generative capabilities and social relations in ways that affect how people generate goals, envisage opportunities for action, and devise and execute health-relevant strategies.

Contextual determinants of action capabilities. Public health practitioners need to know how changes in work, community, or family environments are likely to affect the individual's capacity for self-protective action. Among psychologists, interest in this question owes much to the ecological views of James G. Kelly, who has argued that individual behavior responds to normative expectations of social settings, that behavioral demands of one setting (e.g., work environment) affect behavior in other settings (e.g., family relationships), and that personal change is constrained by access to important community resources and by the behavior's compatibility with enduring communal values or practices (Trickett, 1987). Kelly was influenced by Kurt Lewin and his student Roger Barker, who noted that individual differences in behavior often were more a function of environmental variation than of differences in knowledge, attitudes, intelligence, or personality (Wicker, 1979). Others have combined behavior analysis with Marxist theory (Harris, 1979) to explain individual behavior in terms of constraints imposed by physical environments, technologies of production, and the social roles, organizational structures, and political systems to which modes of production and reproduction give rise (Biglan, Glasgow, \& Singer, 1990). 
Figure 4

Contextual Model Representing Self-Regulation as a Subcomponent of Larger Social and

Environmental Systems

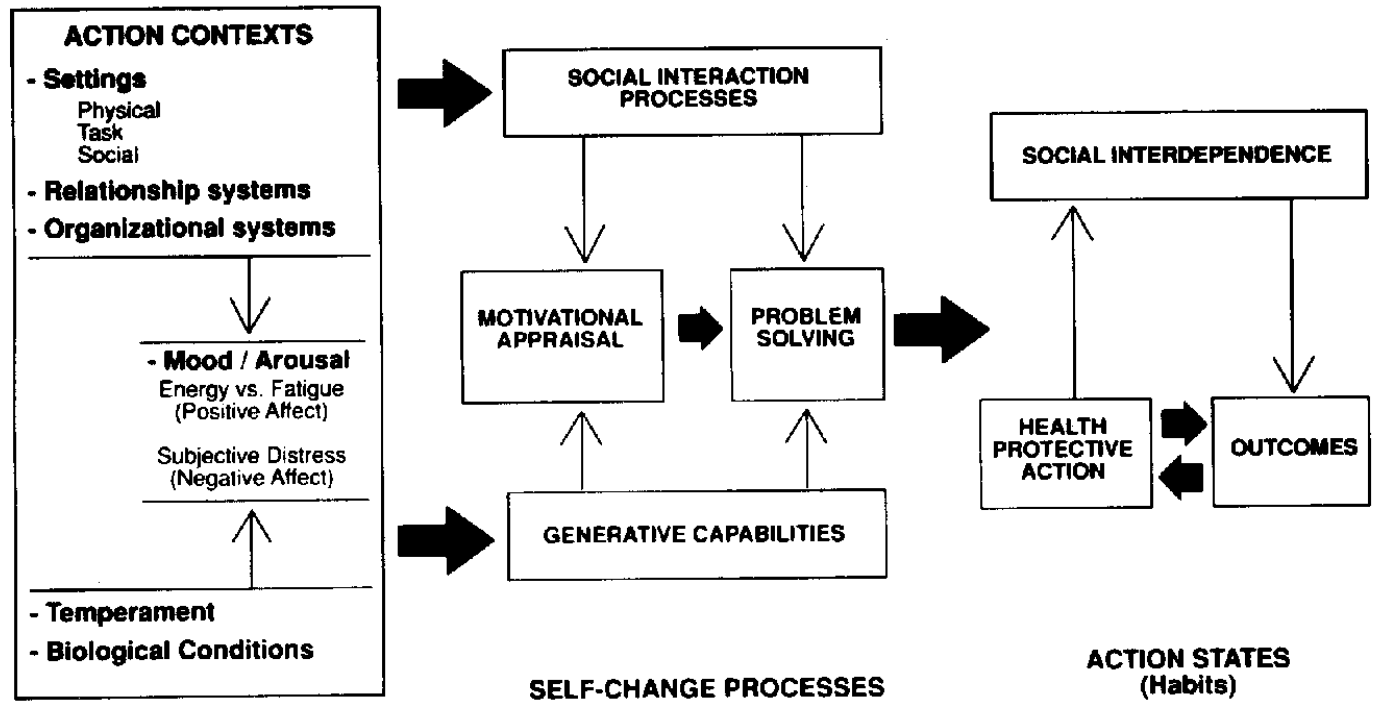

CONTEXTUAL INFLUENCES

Note. The model specifies contextual influences that, by altering microsocial relationships and personal generative capabilities (self-change processes), empower or constrain the development of self-protective habits (action states).

Attempts to explain individual behavior in terms of social organization or structure have a long history in sociology and cultural anthropology (e.g., Giddens, 1979; Parsons, 1949). These literatures suggest that environmental settings and social systems affect personal behavior by channeling a person's interpretations of events, affecting one's biological condition, influencing the formation of close relationships, and interacting with physiological processes to generate mood states that bias cognition and constrain social interaction (e.g., Kohn \& Schooler, 1982). Social action theory (Figure 4) assists in analyzing these influences-and person-environment interactions in general-by characterizing settings and systems in terms of the goals they activate and the personal capabilities, social interactions, motivational appraisals, and action strategies they support.

Settings, defined as the physical features of one's environment, the tasks routinely performed there, and the people composing one's proximal social milieu, influence action goals and strategies by determining access to needed material resources such as health-enhancing foods or exercise facilities (Kerr, Amante, Decker, \& Callen, 1982; Oldridge, 1982), as well as energy resources in the form of information, time, and money. Health promoters have acknowledged the importance of settings by introducing health behavior change programs into the worksite (Cataldo \& Coates, 1986); however, a contextual perspective suggests the importance of restructuring work settings and tasks so as to alter stressful conditions that contribute to health-damaging habits such as smoking and lack of exercise (Johansson et al., 1991).
Social relationships affect personal action by shaping physical and interpersonal environments. Relationships entail a range of benefits, expectations, and obligations that influence health-relevant goals and strategies. ${ }^{3}$ For example, the cooperation of a spouse enhances compliance with diet, smoking, and exercise interventions (Black et al., 1990; Cohen \& Lichtenstein, 1990; Sallis et al., 1987) and with substance abuse treatments (Wiens \& Menustik, 1983), yet relationship systems also impose social obligations that may interfere with self-protective activities (Riley \& Eckenrode, 1986). Peer networks provide contacts with others who can assist with problems, enhance self-efficacy by suggesting effective strategies, and bolster self-esteem by advocating more favorable selfevaluative standards (Thoits, 1986). These relationships also provide social models whose behavior facilitates or inhibits action patterns; consumption of alcohol or tobacco by heavy drinkers or smokers increases in the presence of model who is drinking or smoking (Collins \& Marlatt, 1981; Kniskern, Biglan, Lichtenstein, Fry, \&

\footnotetext{
${ }^{3}$ Social roles and accompanying norms of conduct often are invoked to explain how social systems influence individual behavior. Role theory has been subject to a number of critiques (Lyman \& Scott, 1975; J. F. Scott, 1971), including challenges to the simplistic notion that society supplies the roles to which actors adapt as best they might and to the questionable assumption of strong normative consensus about the behaviors the individual must execute. To quote Giddens (1979), "Social systems are not constituted of roles, but of (reproduced) practices" ( $p$. 117); depending on one's position in the system, these practices entail a range of perogatives and obligations that an actor may decide to activate or carry out.
} 
Bavry, 1983). Similar effects have been demonstrated in eating behaviors (Rosenthal \& McSweeney, 1979).

Organizational structures at the level of government, economic, educational, and health care systems channel individuals' goals, expectations, and strategies in diverse ways (Altman, 1990; Winett et al., 1989). Systems of production, distribution, and promotion, together with government regulatory policies, affect exposure to settings, products, and messages that influence health choices (Gorn \& Goldberg, 1982; Wadden \& Brownell, 1984; Warner, 1986).

Physical settings and social systems both affect and interact with biological structures and processes within the person to create intrapersonal contexts that influence goals and generative capabilities. Physical and social environments modify cognitive skills by affecting the growth of the nervous system and by providing social experiences that change the ways children, adolescents, and adults perceive contingencies, appraise their abilities, and solve problems (Hanna et al., 1990; Nicholls \& Miller, 1984). Biologically based differences in temperament apparent at birth and persisting over the life span influence personal preferences for social interaction, tolerance for novel stimuli, intensity of activity, and emotional arousability; these differences contribute to differential socialization experiences affecting acquisition of health-relevant goals, expectations, and skills (Goldsmith et al., 1987; Kagan, Reznick, \& Snidman, 1988).

Social and biological influences combine to generate mood states, which reflect combinations of energy level or positive affect, and subjective distress or negative affect (Watson \& Pennebaker, 1989). Emotional arousal affects attention deployment; under high arousal, people are less able to detect stimuli, attend to their own behavior, or appraise the long-term consequences of personal decisions (Jarvis, 1982). Mood and arousal also influence the type of health information encoded into memory, the degree to which it is actively processed, and ability to retrieve it later (Bower, 1981; Leventhal, 1970; Petty \& Cacioppo, 1986). Moreover, emotional expression or inhibition may affect behavioral control; for example, anger inhibition in response to provocation has been shown to increase subsequent alcohol consumption by social drinkers (Marlatt, Kosturn, \& Lang, 1975). Emotional distress also can impair interpersonal problem-solving capabilities, thereby affecting relationship support for personal change.

\section{Social Contexts and Empowerment for Self-Change}

Contextual influences determine the success of interventions to promote self-protective behavior. Social action theory provides a useful taxonomy for organizing intervention strategies, as shown in Table 1 . Behavioral research has focused on techniques that facilitate desired action states; far less is known about the ways in which contextual factors influence self-change processes to decide the fate of nascent self-control. This is unfortunate, as interventions to promote habit changes are difficult to implement and sustain without broader social, institutional, or political intervention (Winett et al., 1989).
This concern is evident in the field of community psychology, in which investigators have shown increasing interest in "phenomena of empowerment" (Rappaport, 1987). Empowerment is at once an individual and a social construct, referring both to a sense of personal control, mastery, and power to effect change, and to a group's or organization's ability to control community resources, engage in collective decision making, and achieve shared goals (Chavis \& Wandersman, 1990). Individual empowerment is seen to flow from collective empowerment; political arrangements that empower groups by giving them ownership of material resources, information, and decision-making authority foster individual empowerment of group members by providing direct experience in organizing people, identifying resources, and developing strategies for achieving goals (Zimmerman \& Rappaport, 1988).

A connection between the two types of empowerment is suggested by data showing that people who take an active role in community organizations score higher than do less-involved peers on such empowerment indexes as internal locus of control, belief that people can influence political decisions, self-esteem, and personal sense of mastery (Kieffer, 1984; Zimmerman \& Rappaport, 1988). Although the direction of causation remains to be clarified, the theory is significant in specifying organizational structures that may affect an individual's ability to take self-protective action and in generating guidelines for organizing groups and effecting political and institutional changes to support self-protective behavior (Christenson \& Robinson, 1989).

Social action theory aids this task by specifying mediating mechanisms linking organizational structures to personal health. For example, community empowerment will affect individual community members differently, according to their personal projects, generative capabilities, exposure to social models, and the availability of supportive feedback (Bandura, 1986). Moreover, social action theory suggests that empowerment is not a unitary construct; organizational forms may differ with respect to the number and type of personal goals, capabilities, and action strategies they enhance. Participating in an organization with a rigid ideology and hierarchical leadership structure may foster one's sense of social empowerment (e.g., commitment to the organization's goals and confidence in its political influence) yet fail to enhance individual empowerment defined as capacity for self-protective action (Pargament et al., 1987). Other structures could increase a sense of self-mastery without building the conviction that through collective action people can shape their social destiny or might foster some personal action components (e.g., commitment to self-change goals) at the expense of others (e.g., self-change skills).

Individual empowerment should be enhanced by organizations that (a) encourage their members to identify and pursue tasks that match their personal goals, (b) permit forms of participation that match members' capabilities and allow them to become involved in an incrementally demanding manner, and (c) reward members 
Table 1

Interventions to Facilitate Health Protective Action States, Activate Self-Change Mechanisms, and Create Contexts That Support Sustained Action in Modifying Diet, Obesity, Exercise, Smoking, and Alcohol Use

Intervention

References

Facilitating desired action states

Stimulus control

introduce/remove environmental cues ${ }^{1,2}$

Self-monitoring

Compare personal performance against a monitored behavioral standard ${ }^{2,3,4}$

Reinforcement

Provide desired short-term consequences to support healthenhancing behavior; remove undesired consequences ${ }^{2,5}$

Provide feedback, monetary, material, or social rewards ${ }^{2,3,5,6,7,8}$

Aversive control

Aversive counterconditioning of addictive behavior ${ }^{9}$

Response cost (e.g., fines, loss of advance deposit) ${ }^{2,5,10}$

Behavioral restructuring

Interrupt early components of problem scripts; integrate desired scripts with existing routines; coordinate with scripts of intimate others ${ }^{2,11,12}$

Activating self-change processes

Problem solving

Identify dysfunctional strategies; adopt action orientation; generate and evaluate alternative strategies; formulate action plan ${ }^{13-16}$

Motivational appraisal

Outcome expectancies: Decisional balance sheet procedures $^{16-18}$

Self-efficacy expectancies: Graduated performance and persuasion $^{19}$

Goal structures: Project analysis; values clarification; goal setting ${ }^{2,20,21}$

Generative capabilities

Teach self-control techniques ${ }^{18}$

Provide declarative and procedural action schemas via direct or symbolic (e.g., TV) modelig ${ }^{22}$

Social interaction processes

Peer pressure resistance training ${ }^{23}$

Family self-efficacy training ${ }^{24}$

Family problem-solving training ${ }^{25}$

Creating action contexts

Settings

Provide needed facilities, time, equipment, foods, personnel ${ }^{26,27}$

Relationship systems

Develop support groups; implement buddy systems ${ }^{28,29}$

Organizational structures

Community organization and collective action to change laws and policies affecting work environment; promote healthier food standards; control availability and advertising of healthendangering products ${ }^{30-32}$

Biological conditions

Pharmacologic intervention to alleviate withdrawal symptoms (e.g., nicotine gum) ${ }^{33}$

Mood/Arousal

Relaxation training ${ }^{34}$

Stress management training ${ }^{35}$
1. Brownell, Stunkard, \& Albaum, 1980

2. Kazdin, 1984

3. Martin et al., 1984

4. Scott, Denier, Prue, \& King, 1986

5. Elder, 1987

6. Ewart, Li, \& Coates, 1983

7. Klesges, Vasey, \& Glasgow, 1986

8. Brownell, Marlatt, Lichtenstein, \& Wilson, 1986

9. Wiens \& Menustik, 1983

10. Bowers, Winett, \& Fredriksen, 1987

11. Ewart, 1990

12. Ewart, 1989a
13. Hanna, Ewart, \& Kwiterovich, 1990

14. Kuhl, 1985

15. D'Zurilla, 1986

16. Janis \& Mann, 1977

17. Velicer, DiClemente, Prochaska, \& Brandenburg, 1985

18. Marlatt \& Gordon, 1985

19. Ewart, 1989 a

20. Little, 1983

21. S. H. Schwartz \& Inbar-Saban, 1988

22. Winett, King, \& Altman, 1989

23. Botvin, Baker, Botvin, Filazzola, \& Millman, 1984

24. Taylor, Bandura, Ewart, Miller, \& DeBusk, 1985

25. Ewart, Taylor, Kraemer, \& Agras, 1984

- References describe the techniques and document their effectiveness.

26. King, Carl, Birkel, \& Haskell, 1988

27. Levy, Matthews, Stephenson, Tenney, \& Schucker, 1985

28. Janis, 1983

29. Cohen \& Lichtenstein, 1990

30. DiFranza, Norwood, Garner, \& Tye, 1987

31. Flay, 1987

32. Warner, 1986

33. Goldstein, Niaura, Follick, \& Abrams, 1989

34. Ewart et al., 1987

35. King, Winett, \& Lovett, 1986 
for their contributions. These conditions should be facilitated by a flexible leadership structure, open sharing of information and decision making, moderate group size, and collective control of necessary resources (Zimmerman \& Rappaport, 1988). Research comparing effects of different organizational structures on self-regulatory subprocesses represents a vital yet undeveloped zone of contact between social-cognitive theory, community psychology, and the field of public health.

\section{Social Contexts and Stages of Self-Change}

Social-contextual analysis also has implications for the view that habit changes occur in a sequence of qualitatively distinct behavioral stages (Horn \& Waingrown, 1966; Kristeller \& Rodin, 1984; Prochaska \& DiClemente, 1983). A stage conception is useful if proposed stages reflect different functional mechanisms or processes of self-change. The problem is to identify the critical mechanisms, influences that activate them, and conditions that cause people to move from one behavioral stage to the next. Social action theory specifies mechanisms involving motivational appraisal and problem solving, indicates the order in which they are activated (e.g., appraisal prior to problem solving), and identifies generative capabilities and proximal social interaction processes that must be present before motivation can generate sustained action. Data from studies of smoking cessation suggest that smokers proceed from contemplation to active cessation and abstinence as envisaged here (Prochaska, Velicer, DiClemente, \& Fava, 1988).

What propels people from stage to stage? The model's contextual dimension suggests that social and biological contexts play a critical determining role. Social settings and relationships activate health goals (e.g., parents worry that their smoking may harm their young child), provide helpful action schemas (e.g., a co-worker's successful abstinence provides a model of how to quit), and facilitate the modification of problem scripts (e.g., a spouse agrees to help). Biologic conditions and mood states (e.g., worry about illness symptoms) also activate health goals and may facilitate the implementation of action schemas (e.g., reduced work stress makes it easier to stop smoking). Moreover, contextual influences determine longer term success. For example, a stressful environment, the presence of other smokers, and unpleasant mood states related to nicotine craving and withdrawal are major contextual obstacles to prolonged nonsmoking (Marlatt, Curry, \& Gordon, 1988). Indeed, a social contextual view suggests that maintenance may best be understood as a process of identifying and altering physical, social, and biological contexts that undermine motivational and problem-solving mechanisms of self-change.

\section{Conclusions}

When it is not feasible to remove health threats from human environments, prevention must strive to promote individual self-protective activity by altering laws and policies, rendering environments conducive to personal action, and educating the public. Social action theory
(Figure 4) offers an integrative action schema for defining public health goals and identifying modifiable personal and social-contextual influences that can be activated to encourage self-protective activities. The framework is designed to facilitate interdisciplinary collaboration in public health research by coordinating the perspectives of psychology with perspectives of the biological, epidemiological, and social-organizational sciences.

Social action theory develops new agendas for a public health psychology. Social contextual analysis raises questions concerning the role of social interdependence and interaction in self-regulation and proposes a number of testable hypotheses about processes that mediate connections between environmental changes and personal behavior. To address these questions effectively, it will be helpful for psychologists to receive public health training and to collaborate in research with investigators from other social science disciplines (DeLeon \& Pallak, 1982; Matthews \& Siegel, 1987). By stimulating this collaboration, a social-contextual theory of action provides new directions to advance psychology as a scientific discipline while more widely benefiting the world's peoples.

\section{REFERENCES}

Abelson, R. P. (1981). Psychological status of the script concept. American Psychologist, 36, 715-729.

Altman, D. G. (1990). The social context and health behavior: The case of tobacco. In S. A. Shumaker, E. Schron, \& J. K. Okene (Eds.), The adoption and maintenance of behaviors for optimal health (pp. 241269). New York: Springer.

Anderson, J. R. (1983). The architecture of cognition. Cambridge, MA: Harvard University Press.

Bandura, A. (1969). Principles of behavior modification. New York: Holt, Rinehart, \& Winston.

Bandura, A. (1977). Self-efficacy: Toward a unifying theory of behavioral change. Psychological Review, 84, 191-215.

Bandura, A. (1986). Social foundations of thought and action. Englewood Cliffs, NJ: Prentice-Hall.

Bandura, A. (1988). Self-regulation of motivation and action through goal systems. In V. Hamilton, G. H. Bower, \& N. H. Frijda (Eds.), Cognitive perspectives on emotion and motivation (pp. 37-61). Dordrecht, Netherlands: Kluwer Academic Publishers.

Bandura, A. (1989). Human agency in social cognitive theory. American Psychologist, 44, 1175-1184.

Bandura, A. (in press). Self-efficacy mechanism in physiological activation and health-promoting behavior. In J. Madden IV, S. Matthysse, \& J. Barchas (Eds.), Adaptation, learning, and affect. New York: Raven.

Bandura, A., \& Jeffery, R. W. (1973). Role of symbolic coding and rehearsal processes in observational learning. Journal of Personality and Social Psychology, 26, 122-130.

Bandura, A., O'Leary, A., Taylor, C. B., Gauthier, J., \& Gossard, D. (1987). Perceived self-efficacy and pain control: Opioid and nonopioid mechanisms. Journal of Personality and Social Psychology, 53, 563571.

Bandura, A, \& Schunk, D. H. (1981). Cultivating competence, selfefficacy, and intrinsic interest through proximal self-motivation. Journal of Personality and Social Psychology, 41, 586-598.

Baumann, L. J., \& Leventhal, H. (1985). "I can tell when my blood pressure is up, can't I?" Health Psychology, 4, 203-218.

Becker, D., \& Levine, D. (1987). Risk perceptions, knowledge, and lifestyles in siblings of people with premature coronary disease. The American Jonrnal of Preventive Medicine, 3, 45-50.

Becker, M. H. (1990). Theoretical models of adherence and strategies for improving adherence. In S. Schumaker, E. Schron, \& J. Ockene (Eds.), Handbook of health behavior change (pp. 5-43). New York: Springer. 
Becker, M. H., \& Green, L. W. (1975). A family approach to compliance with medical treatment: A selective review of the literature. International Joumal of Health Education, 18, 173-182.

Berscheid, E. (1983). Emotion. In H. Kelley, E. Berscheid, A. Christensen, J. H. Harvey, T. L. Huston, G. Levinger, E. McClintock, L. A. Peplau, \& D. R. Peterson (Eds.), Close relationships (pp. 110-168). New York: Freeman.

Berscheid, E., Snyder, M., \& Omoto, A. M. (1989). The relationship closeness inventory: Assessing the closeness of interpersonal relationships. Journal of Personality and Social Psychology, 57, 792-807.

Biglan, A., Glasgow, R. E., \& Singer, G. (1990). The need for a science of larger social units: A contextual approach. Behavior Therapy, 21, 195-215.

Black, D. R., Gleser, L. J., \& Kooyers, K. J. (1990). A meta-analytic evaluation of couples weight-loss programs. Health Psychology, 9, 330347.

Black, D. R., \& Scherba, D. S. (1983). Contracting to problem solve versus contracting to practice behavioral weight loss skills. Behavior Therapy, 14, 100-109.

Blackburn, H., Luepker, R., Kline, F. G., Bracht, N., Carlaw, R., Jacobs, D., Mittelmark, M., Stauffer, L., \& Taylor, H. L. (1984). The Minnesota Heart Health Program: A research and demonstration project in cardiovascular disease prevention. In J. D. Matarazzo, S. M. Weiss, J. A. Herd, N. E. Miller, \& S. Weiss (Eds.), Behavioral health: $A$ handbook of health enhancement and disease prevention (pp. 1171-1178). New York: Wiley.

Botvin, G. J., Baker, E., Botvin, E. M., Filazzola, A. D., \& Millman, R. B. (1984). Prevention of alcohol misuse through the development of personal and social competence: A pilot study. Journal of Studies on Alcohol, 45, 550-552.

Bower, G. H. (1981). Mood and memory. American Psychologist, 36, 129-148.

Bowers, T. G., Winett, R. A., \& Fredriksen, L. W. (1987). Nicotine fading, behavioral contracting and extended treatment: Effects on smoking cessation. Addictive Behaviors, 12, 181-184.

Brownell, K. D., Marlatt, A., Lichtenstein, E., \& Wilson, G. T. (1986). Understanding and preventing relapse. American Psychologist, 41 765-782.

Brownell, K. D., Stunkard, A. J., \& Albaum, J. M. (1980). Evaluation and modification of exercise patterns in the natural environment. American Journal of Psychiatry, 137, 1540-1545.

Cantor, N. (1990). From thought to behavior: "Having" and "doing" in the study of personality and cognition. American Psychologist, 45 735-750.

Cantor, N., Norem, J. K., Niedenthal, P. M., Langston, C. A., \& Brower, A. M. (1987). Life tasks, self-concept ideals, and cognitive strategies in a life transition. Journal of Personality and Social Psychology, 53 , 1178-1191.

Carver, C. S., \& Scheier, M. F. (1981). Attention and self-regulation: $A$ control-theory approach to human behavior. New York: Springer-Verlag.

Caspi, A. (1987). Personality in the life course. Journal of Personality and Social Psychology, 53, 1203-1213.

Cataldo, M. F., \& Coates, T. J. (1986). Health and industry: $A$ behavioral medicine perspective. New York: Wiley.

Cervone, D. (1989). Effects of envisioning future activities on self-efficacy judgments and motivation: An availability heuristic interpretation. Cognitive Therapy and Research, 13, 247-261.

Chavis, D. M., \& Wandersman, A. (1990). Sense of community in the urban environment: A catalyst for participation and community development. American Journal of Community Psychology. 18, 55-81.

Christenson, J. A., \& Robinson, J. W. (1989). Community development in perspective. Ames: Iowa State University Press.

Clark, M. S., \& Reis, H. T. (1988). Interpersonal processes in close relationships. Annual Review of Psychology, 39, 609-672.

Cohen, S., \& Lichtenstein, E. (1990). Partner behaviors that support quitting smoking. Journal of Consulting and Clinical Psychology, 58, 304-309.

Collins, R. L., \& Marlatt, G. (1981). Social modeling as a determinant of drinking behavior: Implications for prevention and treatment. $A d$ dictive Behaviors, 6, 233-240.

Coyne, J. C., Wortman, C. B., \& Lehman, D. R. (1988). The other side of support: Emotional overinvolvement and miscarried helping. In
B. Gottlieb (Ed.), Marshalling social support (pp. 305-330). Newbury Park, CA: Sage.

DeLeon, P. H., \& Pallak, M. S. (1982). Public health and psychology: An important, expanding interaction. American Psychologist, 37, 934935.

DiFranza, J. R., Norwood, B. D., Garner, D. W., \& Tye, J. B. (1987). Legislative efforts to protect children from tobacco. Journal of the American Medical Association, 257, 3387-3389.

Donovan, J. E., Jessor, R., \& Costa, F. M. (1988). Syndrome of problem behavior in adolescence: A replication. Journal of Consulting and Clinical Psychology, 56, 762-765.

Dweck, C. S., \& Leggett, E. L. (1988). A social-cognitive approach to motivation and personality. Psychological Review, 95, 256-273.

D'Zurilla, T. J. (1986). Problem-solving therapy: A social competence approach to clinical intervention. New York: Springer.

Eiser, R. J., \& Gentle, P. (1988). Health behavior as goal-directed action. Journal of Behavioral Medicine, 11, 523-535.

Elder, J. P. (1987). Applications of behavior modification to health promotion in the developing world. Social Science and Medicine, 24, 335-349.

Elder, J. P., Schmid, T. L., Hovell, M. F., Molgaard, C. A., \& Graeff, J. A. (1989). The global relevance of behavioral medicine: Health and child survival in the developing world. Annals of Behavioral Medicine, $11,12-17$.

Emmons, R. A. (1986). Personal strivings: An approach to personality and subjective well-being. Joumal of Personality and Social Psychology, $51,1058-1068$.

Emmons, R. A., Diener, E., \& Larsen, R. J. (1986). Choice and avoidance of everyday situations and affect congruence: Two models of reciprocal interactionism. Journal of Personality and Social Psychology, 51, 815826.

Emmons, R. A., \& King, L. A. (1988). Conflict among personal strivings: Immediate and long-term implications for psychological and physical well-being. Journal of Personality and Social Psychology, 54, 10401048.

Emmons, R. A., \& King, L. A. (1989). Personal striving differentiation and affective reactivity. Journal of Personality and Social Psychology $56,478-484$.

Ewart, C. K. (1989a). Changing dietary behavior: A social action theory approach. Clinical Nutrition, 8, 9-16.

Ewart, C. K. (1989b). Psychological effects of resistive weight training: Implications for cardiac patients. Medicine and Science in Sports and Exercise, 21, 683-689.

Ewart, C. K. (1990). A social problem-solving approach to behavior change in coronary heart disease. In S. Schumaker, E. Schron, \& J. Ockene (Eds.), Handbook of health behavior change (pp. 153-190). New York: Springer.

Ewart, C. K. (in press). Health promotion and disease prevention: A social action conception of compliance behavior. In N. Krasnegor, L. Epstein, \& S. Johnson (Eds.), Developmental aspects of health compliance behavior. Bethesda, MD: National Institute of Child Health and Human Development.

Ewart, C. K., Burnett, K. F., \& Taylor, C. B. (1983). Communication behaviors that affect blood pressure: An A-B-A-B analysis of marital interaction. Behavior Modification, 7, 331-344.

Ewart, C. K., Harris, W. L., Iwata, M., Bullock, R., Coates, T. J., Simons, B. (1987). Feasibility and effectiveness of school-based relaxation to lower blood pressure. Health Psychology, 6, 399-416.

Ewart, C. K., Li, V. C., \& Coates, T. J. (1983). Increasing physicians' anti-smoking influence by applying an inexpensive feedback technique. Journal of Medical Education, 58, 468-473.

Ewart, C. K., Stewart, K. J., Gillilan, R. E., \& Kelemen, M. H. (1986). Self-efficacy mediates strength gains during circuit weight training in men with coronary artery disease. Medicine and Science in Sports and Exercise, 18, 531-540.

Ewart, C. K., Stewart, K. J., Gillilan, R. E., Keleman, M. H., Valenti, S. A., Manley, J. D., \& Kelemen, M. D. (1986). Usefulness of selfefficacy in predicting overexertion during programmed exercise in coronary artery disease. American Journal of Cardiology. 57, 557561 .

Ewart, C. K., Taylor, C. B., Kraemer, H. A., \& Agras, W. S. (1984). Reducing blood pressure reactivity during interpersonal conflict: Ef- 
fects of marital communication training. Behavior Therapy, 15, 473484.

Ewart, C. K., Taylor, C. B., Kraemer, H. A., \& Agras, W. S. (1991). High blood pressure and marital discord: Not being nasty matters more than being nice. Health Psychology, 10, 155-163.

Ewart, C. K., Taylor, C. B., Reese, L. B., \& DeBusk, R. F. (1983). The effects of early post myocardial infarction exercise testing on selfperception and subsequent physical activity. American Joumal of Cardiology, 51, 1076-1080.

Faden, R. R. (1987). Health psychology and public health. In G. Stone, S. Weiss, J. Matarazzo, N. Miller, J. Rodin, C. Belar, M. Follick, M. J., \& J. Singer (Eds.), Health psychology: A discipline and a profession (pp. 165-173). Chicago: University of Chicago Press.

Farquhar, J. W., Fortman, S. P., Maccoby, N., Haskell, W. L., Williams, P. T., Flora, J. A., Taylor, C. B., Brown, B. W., Solomon, D. S., \& Hulley, S. B. (1985). The Stanford Five-City Project: Design and methods. American Journal of Epidemiology, 63, 171-182.

Fehrenbach, A. M. B., \& Peterson, L. (1989). Parental problem-solving skills, stress, and dietary compliance in phenylketonuria. Journal of Consulting and Clinical Psychology, 57, 237-241.

Fishbein, M., \& Ajzen, I. (1975). Belief, attitude, intention, and behavior An introduction to theory and research. Reading, MA: Addison-Wesley.

Flay, B. R. (1987). Mass media and smoking cessation: A critical review. American Journal of Public Health, 77, 153-160.

Ford, D. H. (1987). Humans as self-constructing living systems: A developmental perspective on personality and behavior. Hillsdale, $\mathrm{NJ}$ : Erlbaum.

Ford, M. E. (1982). Social cognition and social competence in adolescence. Developmental Psychology, 18, 323-340.

Ford, M. E., \& Nichols, C. W. (1987). A taxonomy of human goals and some possible applications. In M. E. Ford \& D. H. Ford (Eds.), Humans as self-constructing living systems: Putting the framework to work (pp. 289-311). Hillsdale, NJ: Erlbaum.

Geller, E. S., Winett, R. A., \& Everett, P. B. (1982). Preserving the environment: New strategies for behavior change. New York: Pergamon.

Giddens, A. (1979). Central problems in social theory: Action, structure, and contradiction in social analysis. Berkeley: University of California Press.

Glasgow, R. E., Toobert, D. J., Riddle, M., Donnelly, J., \& Calder, D. (1989). Diabetes-specific social learning variables and self-care behaviors among persons with Type II diabetes. Health Psychology, 8. 285-303.

Goldsmith, H. H., Buss, A. H., Plomin, R., Rothbart, M. K., Thomas, A., Chess, S., Hinde, R. A., \& McCall, R. B. (1987). Roundtable: What is temperament? Four approaches. Child Development, 58, 505529.

Goldstein, M. G., Niaura, R., Follick, M. J., \& Abrams, D. B. (1989). Effects of behavioral skills training and schedule of nicotine gum administration on smoking cessation. American Journal of Psychiatry, $146,56-60$.

Gorn, G. T., \& Goldberg, M. E. (1982). Behavioral evidence of the effects of televised food messages on children. Journal of Consumer Research. 9, 200-205.

Gottman, J., Notarius, C., Gonso, J., \& Markman, H. (1976). A couple's guide to communication. Champaign, IL: Research Press.

Graves, T., Meyers, A. W., \& Clark, L. (1988). An evaluation of parental problem-solving training in the behavioral treatment of childhood obesity. Joumal of Consulting and Clinical Psychology. 56, 246-250.

Hanna, K. J., Ewart, C. K., \& Kwiterovich, P. O. (1990). Child problemsolving competence, behavioral adjustment, and adherence to lipidlowering diet. Patient Education and Counseling, 16, 119-131.

Harris, M. (1979). Cultural materialism: The struggle for a science of culture. New York: Random House.

Heller, K., Swindle, R. W., \& Dusenbury, L. (1986). Component social support processes: Comments and integration. Journal of Consulting and Clinical Psychology, 54, 466-470.

Horn, D., \& Waingrown, S. (1966). Some dimensions of a model for smoking behavior change. American Journal of Public Health, 56, 21.

Hyland, M. E. (1988). Motivational control theory: An integrative framework. Journal of Personality and Social Psychology, 55, 642651.

Jacobson, N. S., \& Holzworth-Monroe, A. (1986). Marital therapy: A social-learning-cognitive perspective. In N. S. Jacobson \& A. S. Gurman (Eds.), Clinical handbook of marital therapy (pp. 29-70). New York: Guilford Press.

Jacobson, N. S., \& Margolin, G. (1979). Marital therapy: Strategies based on social learning and behavior exchange principles. New York: Bruner-Mazel.

James, W. (1950). The principles of psychology (Vol. 2, pp. 561-562). New York: Dover. (Original date of publication 1890)

Janis, I. L. (1983). The role of social support in adherence to stressful decisions. American Psychologist, 38, 143-160.

Janis, I. L., \& Mann, L. (1977). Decision making: A psychological analysis of conflict, choice, and commitment. New York: Free Press.

Janoff-Bulman, R. (1989). Assumptive worlds and the stress of traumatic events: Applications of the schema construct. Social Cognition, 3 , 113-136.

Janz, N. K., \& Becker, M. H. (1984). The health belief model: A decade later. Health Education Quarterly, 11, 1-47.

Jarvis, I. L. (1982). Decision making under stress. In L. Goldberger \& S. Breznitz (Eds.), Handbook of stress: Theoretical and clinical aspects (pp. 69-87). New York: Free Press.

Jeffery, R. W. (1989). Risk behaviors and health: Contrasting individual and population perspectives. American Psychologist, 44, 1194-1202.

Jessor, R., Chase, J. A., \& Donovan, J. E. (1980). Psychosocial correlates of marijuana use and problem drinking in a national sample of adolescents. American Journal of Public Health, 70, 604-613.

Johansson, G., Johnson, J. V., \& Hall, E. M. (1991). Smoking and sedentary behavior as related to work organization. Social Science and Medicine, 7, 837-846.

Kagan, J., Reznick, J. S., \& Snidman, N. (1988). Biological bases of childhood shyness. Science, 240, 167-171.

Kanfer, F. H. (1977). The many faces of self-control, or behavior modification changes its focus. In R. B. Stuart (Ed.), Behavioral self-management: Strategies, techniques, and outcomes (pp. 1-48). New York: Bruner-Mazel.

Kanfer, F. H. (1980). Self-management methods. In F. H. Kanfer \& A. P. Goldstein (Eds.), Helping people change (2nd ed., pp. 334-389). New York: Pergamon.

Kazdin, A. E. (1984). Behavior modification in applied settings. Homewood, IL: Dorsey Press.

Kerr, G. R., Amante, P., Decker, M., \& Callen, P. W. (1982). Ethnic patterns of salt purchase in Houston, Texas. American Journal of Epidemiology, 115, 906-916.

Kieffer, C. (1984). Citizen empowerment: A developmental perspective. Prevention in Human Services, 3, 9-36.

Kihlstrom, J. F. (1987). The cognitive unconscious. Science, 237, 14451452.

King, A. C., Carl, F. N., Birkel, L. P., \& Haskell, W. L. (1988). Increasing exercise among blue-collar employees: The tailoring of worksite programs to meet specific needs. Preventive Medicine, 17, 357-365.

King, A. C., Winett, R. A., \& Lovett, S. B. (1986). Enhancing coping behaviors in at-risk populations: The effects of time-management instruction and social support in women from dual-earner families. Behavior Therapy, 17, 57-66.

Klesges, R. C., Vasey, M. M., \& Glasgow, R. E. (1986). A worksite smoking modification competition: Potential for public health impact. American Journal of Public Health, 76, 198-200.

Kluwe, R. H., \& Friedrichsen, G. (1985). Mechanisms of control and regulation in problem solving. In J. Kuhl \& J. Beckmann (Eds.), Action control: From cognition to behavior (pp. 183-218). Berlin, Germany: Springer Verlag.

Kniskern, J., Biglan, A., Lichtenstein, E., Fry, D., \& Bavry, J. (1983). Peer modeling effects in the smoking behavior of teenagers. Addictive Behaviors, 8, 129-132.

Kohn, M. L., \& Schooler, C. (1982). Job conditions and personality: A longitudinal assessment of their reciprocal effects. American Journal of Sociology, 87, 1257-1286.

Kristeller, J. L., \& Rodin, J. (1984). A three-stage model of treatment continuity: Compliance, adherence, and maintenance. In A. Baum, S. Taylor, \& J. Singer (Eds.), Handbook of psychological aspects of health (pp. 85-112). Hillsdale, NJ: Erlbaum.

Kuhl, J. (1985). Volitional mediators of cognition-behavior consistency: Self-regulatory processes and action versus state orientations. In J. 
Kuhl \& J. Beckmann (Eds.), Action control: From cognition to behavior (pp. 101-128). Berlin, Germany: Springer Verlag.

Kuhn, T. S. (1977). The nature of scientific revolutions (2nd ed.). Chicago: University of Chicago Press.

Langer, E. J. (1989). Mindfulness. Reading, MA: Addison-Wesley.

Leventhal, H. (1970). Findings and theory in the study of fear communications. In L. Berkowitz (Ed.), Advances in experimental social psychology (Vol. 5, pp. 119-186). San Diego, CA: Academic Press.

Leventhal, H., \& Cleary, P. D. (1980). The smoking problem. Psychological Bulletin, 88, 370-405.

Leventhal, H., Cleary, P. D., Safer, M. A., \& Gutman, M. (1980). Cardiovascular risk modification by community-based programs for lifestyle change: Comments on the Stanford Study. Journal of Consulting and Clinical Psychology, 48, 150-158.

Leventhal, H., Meyer, D., \& Gutman, M. (1980). The role of theory in the study of compliance to high blood pressure regimens. In R. B. Haynes, M. E. Mattson, \& T. O. Engebretson (Eds.), Patient compliance to prescribed antihypertensive medication regimens: $A$ report to the National Heart, Lung, and Blood Institute (pp. 1-58). Bethesda, MD: National Heart, Lung, and Blood Institute.

Leventhal, H., Meyer, D., \& Nerenz, D. (1980). The common-sense representation of illness danger. In S. Rachman (Ed.), Medical psychology (Vol. 2, pp. 7-30). New York: Pergamon.

Leventhal, H., Zimmerman, R., \& Gutman, M. (1984). Compliance: A self-regulation perspective. In W. D. Gentry (Ed.), Handbook of be havioral medicine (pp. 369-436). New York: Guilford.

Levine, D. M., Green, L. W., Deeds, S. G., Chwalow, A. J., Russell, R. P., \& Finlay, J. F. (1979). Health education for hypertensive patients. Journal of the American Medical Association, 241, 1700-1703.

Levy, A. S., Matthews, O., Stephenson, M., Tenney, J. E., \& Schucker, R. E. (1985). The impact of a nutrition information program on food purchases. Journal of Public Policy and Marketing, 4, 1-13.

Ley, P. (1977). Psychological studies of doctor-patient communication. In S. Rachman (Ed.), Contributions to medical psychology (Vol. 1, pp. 9-38). New York: Pergamon.

Lichtman, R., Taylor, S., Wood, J., Bluming, A., Dosik, G., \& Leibowitz, R. (1984). Relations with children after breast cancer: The motherdaughter relationship at risk. Journal of Psychosocial Oncology, 2, 119.

Linville, P. W., \& Clark, L. F. (1989). Production systems and social problem solving: Specificity, flexibility, and expertise. In R. S. Wyer, Jr., \& T. K. Srull (Eds.), Advances in social cognition (Vol. 2, pp. 131152). Hillsdale, NJ: Erlbaum.

Little, B. R. (1983). Personal projects: A rationale and method for investigation. Environment and Behavior, 15, 273-309.

Locke, E. A., Shaw, K. N., Saari, L. M., \& Latham, G. P. (1981). Goal setting and task performance: 1969-1980. Psychological Bulletin, 90, $125-152$.

Lyman, S., \& Scott, B. M. (1975). The drama of social reality. New York: Oxford University Press.

Mandler, G. (1975). Mind and emotion. New York: Wiley,

Manne, S. L., \& Zautra, A. J. (1989). Spouse criticism and support: Their association with coping and psychological adjustment among women with rheumatoid arthritis. Journal of Personality and Social Psychology, 56, 608-617.

Marlatt, G. A., Curry, S., \& Gordon, J. R. (1988). A longitudinal analysis of unaided smoking cessation. Journal of Consulting and Clinical Psychology, 56, 715-720.

Marlatt, G. A., \& Gordon, J. R. (1985). Relapse prevention: Maintenance strategies in the treatment of addictive behavior. New York: Guilford Press.

Marlatt, G. A., Kosturn, C. F., \& Lang, A. R. (1975). Provocation to anger and opportunity for retaliation as determinants of alcohol consumption in social drinkers. Journal of Abnormal Psychology, 84, 652-659.

Martin, J. E., Dubbert, P. M., Katell, A. D., Thompson, J. K., Raczynski, J. R., Lake, M., Smith, P. O., Webster, J. S., Sikora, T., \& Cohen, R. E. (1984). Behavioral control of exercise in sedentary aduits: Studies 1 through 6. Journal of Consulting and Clinical Psychology, 52, 795811.

Matthews, K. A., \& Siegel, J. M. (1987). Training health psychologists in schools of public health. In C. Stone, S. M. Weiss, J. D. Matarazzo, et al. (Eds.), Health psychology: A discipline and a profession (pp. 481-491). Chicago: University of Chicago Press.

McCaul, K. D., \& Malott, J. M. (1984). Distraction and coping with pain. Psychological Bulletin, 95, 516-533.

McFall, R. M. (1982). A review and reformulation of the concept of social skills. Behavioral Assessment, 4, 1-33.

Meyer, D., Leventhal, H., \& Gutman, M. (1985). Common-sense models of illness: The example of hypertension. Health Psychology, 4, 115135.

Morisky, D. E., Levine, D. M., Green, L. W., Shapiro, S., Russell, R. P., \& Smith, C. R. (1983). Five-year blood pressure control and mortality following health education for hypertensive patients. American Journal of Public Health. 73, 153-162.

Nezu, A. M. (1986). Efficacy of a social problem-solving therapy approach for unipolar depression. Journal of Consulting and Clinical Psychology, 54, 196-202.

Nezu, A. M., \& Perri, M. G. (1989). Social problem-solving therapy for unipolar depression: An initial dismantling investigation. Journal of Consulting and Clinical Psychology, 57, 408-413.

Nicholls, J. G., \& Miller, A. T. (1984). Development and its discontents: The differentiation of the concept of ability. In J. G. Nicholls (Ed.), The development of achievement motivation (pp. 185-218). Greenwich, CT: JAI Press.

Nuttin, J. (1984). Motivation, planning, and action: $A$ relational theory of behavioral dynamics. Hillsdale, NJ: Erlbaum.

Oldridge, N. B. (1982). Compliance and exercise in primary and secondary prevention of coronary heart disease: A review. Preventive Medicine, 11, 56-70.

Olson, D. H., Sprenkle, D. H., \& Russell, C. S. (1979). Circumplex model of marital and family systems: I. Cohesion and adaptability dimensions, family types and clinical applications. Family Process, 18, 3-28.

Pargament, K. I., Echemendia, R. J., Johnson, S., Cook, P., McGrath, C., Myers, J., \& Brannick, M. (1987). The conservative church: Psychosocial advantages and disadvantages. American Journal of Community Psychology, 15, 269-286.

Parsons, T. (1949). The structure of social action. Glencoe, NY: Free Press.

Petty, R. E., \& Cacioppo, J. T. (1986). Communication and persuasion: Central and peripheral routes to attitude change. New York: SpringerVerlag.

Prochaska, J. O., \& DiClemente, C. C. (1983). Stages and processes of self-change of smoking: Toward an integrative model of change. Journal of Consulting and Clinical Psychology, 51, 390-395.

Prochaska, J. O., Velicer, W. F., DiClemente, C. C., \& Fava, J. (1988). Measuring processes of change: Applications to the cessation of smoking. Journal of Consulting and Clinical Psychology, 56, 520S28.

Rappaport, J. (1987). Terms of empowerment/exemplars of prevention: Toward a theory of community psychology. American Journal of Community Psychology, 15, 121-148.

Riley, D., \& Eckenrode, J. (1986). Social ties: Subgroup differences in costs and benefits. Journal of Personality and Social Psychology, 51, 770-778.

Rippletoe, R. A., \& Rogers, R. W. (1987). Effects of components of protection-motivation theory on adaptive and maladaptive coping with a health threat. Journal of Personality and Social Psychology, $52,596-604$

Rodriguez, M. L., Mischel, W., \& Shoda, Y. (1989). Cognitive person variables in the delay of gratification of older children at risk. Journal of Personality and Social Psychology, 57, 358-367.

Rogers, R. W. (1983). Cognitive and physiological processes in fear appeals and attitude change: A revised theory of protection motivation. In J. T. Cacioppo, R. E. Petty, \& D. Shapiro (Eds.), Social psychophysiology: A sourcebook (pp. 153-176). New York: Guilford.

Rosenthal, B., \& McSweeney, F. K. (1979). Modeling influences on eating behaviors. Addictive Behaviors, 4, 205-214.

Ruehlman, L. S. (1985). Depression and affective meaning for current concerns. Cognitive Therapy and Research, 9, 553-560.

Ruehlman, L. S., \& Wolchik, S. A. (1988). Personal goals and interpersonal support and hindrance as factors in psychological distress and 
well-being. Journal of Personality and Social Psychology, 55, 293301.

Runyan, C. W., DeVellis, R. F., DeVellis, B. McE., \& Hochbaum, G. M. (1982). Health psychology and the public health perspective: In search of the pump handle. Health Psychology, 1, 169-180.

Sackett, D. L., Anderson, G. D., Milner, R., Feinleib, M., \& Kannel, W. B. (1975). Concordance for coronary risk factors among spouses. Circulation, 52, 589-595.

Sallis, J. F., Grossman, R. M., Pinski, R. B., Patterson, T. L., \& Nader, P. R. (1987). The development of scales to measure social support for diet and exercise behaviors. Preventive Medicine, 16, 825-836.

Schank, R. C., \& Abelson, R. P. (1977). Scripts, plans, goals, and under standing. Hillsdale, NJ: Erlbaum.

Schwartz, G. E. (1983). Disregulation theory and disease: Applications to the repression/cerebral disconnection/cardiovascular disorder hypothesis. International Review of Applied Psychology, 32, 95118.

Schwartz, S. H., \& Inbar-Saban, N. I. (1988). Value self-confrontation as a method to aid in weight loss. Journal of Personality and Social Psychology, 54, 396-404.

Scott, J. F. (1971). Internalization of norms: A sociological theory of moral commitment. Englewood Cliffs, NJ: Prentice-Hall.

Scott, R. R., Denier, C. A., Prue, D. M., \& King, A. C. (1986). Worksite smoking interventions with nursing professionals: Long-term outcome and relapse assessment. Journal of Consulting and Clinical Psychology. 54, 809-813.

Seeman, J. (1989). Toward a model of positive health. American Psychologist, 44, 1099-1109.

Sexton, M. McD. (1979). Behavioral epidemiology. In O. F. Pomerleau \& J. P. Brady (Eds.), Behavioral medicine: Theory and practice (pp. 3-21). Baltimore: Williams \& Wilkins.

Slater, M. D. (1989). Social influences and cognitive control as predictors of self-efficacy and eating behavior. Cognitive Therapy and Research. 13, 231-245.

Stunkard, A. J., \& Penick, S. B. (1979). Behavior modification in the treatment of obesity. Archives of General Psychiatry. 36, 801806 .

Surgeon General. (1979). Healthy people: The Surgeon General's report on health promotion and disease prevention (DHEW PHS Pub. No. 79-55071). Washington, DC: U.S. Department of Health, Education, \& Welfare.

Taylor, C. B., Bandura, A., Ewart, C. K., Miller, N. H., \& DeBusk, R. F. (1985). Exercise testing to enhance wives' confidence in their husband's capability soon after clinically uncomplicated myocardial infarction. American Journal of Cardiology. 55, 636-628.
Thoits, P. A. (1986). Social support as coping assistance. Journal of Consulting and Clinical Psychology, 54, 416-423.

Trickett, E. J. (1987). Community interventions and health psychology: An ecologically oriented perspective. In C. Stone, S. M. Weiss, J. D. Matarazzo, et al. (Eds.), Health psychology: A discipline and a profession (pp. 151-163). Chicago: University of Chicago Press.

Velicer, W. F., DiClemente, C. C., Prochaska, J. O., \& Brandenburg, N. (1985). Decisional balance measure for assessing and predicting smoking status. Journal of Personality and Social Psychology, 48, 1279-1289.

Wadden, T. A., \& Brownell, K. D. (1984). The development and modification of dietary practices in individuals, groups, and lange populations. In J. D. Matarazzo, S. M. Weiss, J. A. Herd, N. E. Miller, \& S. Weiss (Eds.), Behavioral health: $A$ handbook for health enhancement and disease prevention (pp. 608-631). New York: Wiley.

Warner, K. E. (1986). Smoking and health implications of a change in the federal cigarette excise tax. Journal of the American Medical Association, 255, 1028-1032.

Watson, D. W., \& Pennebaker, J. W. (1989). Health complaints, stress, and distress: Exploring the central role of negative affectivity. Psychological Review, 96, 234-254.

Weinstein, N. D. (1988). The precaution adoption process. Health Psychology, 7, 355-386.

Wicker, A. W. (1979). An introduction to ecological psychology. Monterey, CA: Brooks-Cole.

Wiens, A. N., \& Menustik, C. E. (1983). Treatment outcome and patient characteristics in an aversion therapy program for alcoholism. American Psychologist, 1089-1096.

Wilensky, R. (1983). Planning and understanding: A computational approach to human reasoning. Reading, MA: Addison-Wesley.

Williams, A. F. (1982). Passive and active measures for controlling disease and injury: The role of health psychologists. Health Psychology, 1 , 399-409.

Winett, R. A., King, A. C., \& Altman, D. G. (1989). Health psychology and public health. New York: Pergamon.

Winfrey, L. L., \& Goldfried, M. R. (1986). Information processing and the human change process. In R. E. Ingram (Ed.), Information processing approaches to clinical psychology (pp. 241-258). San Diego, CA: Academic Press.

Woodward, W. R. (1982). The "discovery" of social behaviorism and social learning theory, 1870-1980. American Psychologist, 37, 396410.

Zimmerman, M. A., \& Rappaport, J. (1988). Citizen participation, perceived control, and psychological empowerment. American Journal of Community Psychology, 16, 725-750. 